\title{
PROBLEMATIKA PENDISTRIBUSIAN ZAKAT DALAM PEMBERDAYAAN EKONOMI MASYARAKAT (Studi Kasus di Desa Bunut Baok Kecamatan Praya)
}

\section{Muhammad Taisir *}

\begin{abstract}
Abstrak: Penelitian ini bertujuan untuk mengetahui dan mendeskripsikan pemahaman masyarakat Desa Bunut Baok tentang pemanfaatan zakat, mekanisme dan problematika pendistribusian zakat di Desa Bunut Baok. Penelitian ini termasuk penelitian kualitatif dengan pendekatan deskriptif. Hasil temuan penelitian ini menguraikan bahwa, pertama, masyarakat tentang pemanfaatan zakat antara lain: (a) belum memahami jenis-jenis zakat mal; (b) belum ada upaya merubah bentuk zakat ke bentuk lainnya; (c) pemanfaatan zakat bersifat tradisional, lebih cenderung bersifat konsumtif. Kedua, mekanisme pendistribusian zakat di desa Bunut Baok bersifat tradisional dan individual. Ketiga, problematika pendistribusian zakat di desa Bunut Baok antara lain: (1) zakat disalurkan hanya untuk memenuhi kebutuhan pokok sehari-hari atau konsumtif; (2) tidak ada lembaga yang mengelola dan mendistribusikan zakat kepada masyarakat; (3) muఇakki menyalurkan zakat secara individual; (4) belum ada upaya penyaluran zakat dalam bentuk lain, misalnya beasiswa atau modal usaha dan; (5) belum ada upaya mengumpulkan dan menyalurkan zakat profesi.
\end{abstract}

Kata kunci: distribusi zakat, pemberdayaan ekonomi masyarakat, Desa Bunut Baok Praya.

*Jurusan PAI FITK IAIN Mataram. Email: iching74@yahoo.com 


\section{Pendahuluan}

emiskinan merupakan masalah krusial dan klasik yang
menjadi kenyataan dalam kehidupan manusia. Karenanya
ia senantiasa menjadi issu yang hangat dan menarik. Bahkan kemiskinan telah menjadi tema sentral dalam berbagai diskusi dan kegiatan-kegiatan pemberdayaan. Hal ini disebabkan karena kemiskinan dapat menajdi titik awal persoalan-persoalan sosial lainnya. Mulanya adalah kemiskinan, lalu pengangguran, kemudian kekerasan dan kejahatan.

Kemiskinan dapat dilihat dari berbagai indikator. Menurut bank dunia, kemiskinan diukur berdasarkan pendapatan perkapita pertahun, yaitu $50 \$$ untuk daerah pedesaan dan $75 \$$ untuk daerah perkotaan. Sedangkan UNDP menetapkan garis kemiskinan sebesar $2 \$$ per kapita per hari. Sayogya menggunakan pendapatan ekuivalen beras; untuk daerah pedesaan sebanyak $240 \mathrm{~kg}$ dan untuk kota $360 \mathrm{~kg}$ perkapita per tahun. Sementara itu, Badan Pusat Statistik (BPS) menggunakan ukuran pendapatan untuk memenuhi kebutuhan bahan makan 2.100 kalori per kapita per hari (Tambunan, 2014:51).

Di Indonesia, meskipun angka kemiskinan mengalami fluktuasi setiap tahunnya, namun masih terbilang cukup tinggi. Berdasarkan data Badan Pusat Statistik (BPS) bahwa penduduk miskin Indonesia pada tahun 2014 mencapai 27,73 juta jiwa atau sekitar 10,96 persen penduduk Indonesia secara keseluruhan. Pemerintah Indonesia memberikan perhatian yang sangat serius dalam mengatasi kemiskinan dan mengalokasikan dana yang sangat besar dalam upaya-upaya mengatasinya. Kemiskinan sudah menjadi masalah yang multidimensional, tidak lagi hanya sebatas ketidakmampuan ekonomi, tetapi juga kegagalan dalam memenuhi hak-hak dasar dan perbedaan perlakuan bagi seseorang atau sekelompok orang dalam menjalani kehidupan secara bermartabat.

Islam, sebagai agama mayoritas penduduk Indonesia sebenarnya memiliki konsep ideal dan matang untuk membangun keteraturan sosial berbasis saling tolong menolong dan gotong royong. Islam mempunyai perhatian yang sangat tinggi untuk melepaskan orang 
miskin dan kaum dhuafa dari belenggu kemiskinan dan keterbelakangan. Islam sangat konsisten dalam mengentas kemiskinan. Salah satunya adalah melalui optimalisasi peran zakat. Zakat merupakan sedekah wajib yang besarnya telah ditentukan dalam al-Qur'an dan Hadis. Melalui pendistribusian zakat, kehidupan orang-orang fakir, miskin, dan orang-orang menderita lainnya akan terperhatikan dengan baik (Hafidhuddin, dkk, 2008:4).

Penghimpunan dana zakat dapat dilakukan dengan berbagai cara atau strategi, antara lain dengan pemanfaatan sejumlah produk perbankan dan fasilitas transfer, pungutan langsung dari karyawan oleh wakil yang ditunjuk perusahaan, melalui iklan media massa, membuka gerai penampungan zakat, pengembangan program kemitraan, melalui korespodensi dan lewat kontak kepanitiaan.

Zakat yang sudah terkumpul dapat disalurkan secara individual maupun organisasi pengelola zakat, misalnya melalui Badan Amil Zakat yang dibentuk oleh pemerintah dan Lembaga Amil Zakat yang dibentuk oleh masyarakat yang dikukuhkan serta dibina oleh pemerintah. Badan Amil Zakat dan Lembaga Amil Zakat merupakan organisasi atau lembaga yang berkompeten dalam mengumpulkan dan menyalurkan zakat untuk pemberdayaan ekonomi masyarakat yang dikelola secara profesioanal dan oftimal.

Pendistribusian zakat tidak hanya diperuntukan untuk pemenuhan kebutuhan yang hanya bersifat konsumtif, namun harus diarahkan pada hal yang bersifat produktif untuk mewujudkan daya ekonomi masyarakat yang mandiri. Penggunaan zakat untuk konsumtif hanyalah untuk hal-hal yang bersifat darurat. Artinya, ketika ada mustabiq (orang yang berhak menerima zakat) yang tidak mungkin untuk dibimbing untuk mempunyai usaha mandiri atau memang untuk kepentingan mendesak, maka penggunaan konsumtif dapat dilakukan.

Model pendistribusian zakat yang tradisional dan tidak tepat sasaran serta paradigma lama zakat, ketika perolehan zakat dari masyarakat dibagikan langsung habis kepada yang berhak, biasanya untuk kebutuhan konsumtif. Hal ini didukung oleh Ahmad Mubariq bahwa zakat disalurkan untuk memenuhi konsumsi pokok 
kebutuhan yang habis dipakai dari hari ke hari. Meskipun mampu membantu fakir miskin memenuhi kebutuhan hidup yang mendesak, cara pemanfaatan zakat seperti ini cenderung mengabadikan si penerima dalam situasi kemiskinannya. Model pendistribusiannya pun terkadang kurang sensitif terhadap harkat kemanusiaan. Biasanya dibagikan dengan antrean panjang dan berdesak-desakkan (Mubariq, 2005: 32). Dalam beberapa pengamatan, di BAZ pun karena pengelola zakat kurang professional dan kompeten, maka mereka kebingungan dalam mendistribusikan dana zakat sehingga yang terjadi adalah distribusi zakat yang tradisional dan tidak tepat sasaran.

Sebagian masyarakat muslim masih melaksanakan kewajiban zakat secara individual secara langsung atau melalui tokoh-tokoh agama seperti kyai atau lembaga sosial yang dipimpinnya seperti pesantren. Praktek semacam ini biasanya didasarkan pada keyakinan yang berkembang di masyarakat bahwa zakat merupakan perintah agama yang bersifat pribadi dan bukan kewajiban sosial yang harus diatur melalui mekanisme di luar ketentuan agama. Hal lain juga oleh Hafidhuddin dinyatakan sebagai salah satu penyebab belum optimalnya pengumpulan zakat dan belum dirasakan fungsinya karena pengetahuan serta pemahaman masyarakat terhadap harta yang wajib dikeluarkan zakatnya masih terbatas pada sumber-sumber konvensional yang secara jelas dinyatakan dalam al Qur'an dan Hadits dengan persyaratan tertentu (Hafidhuddin, 2002:2). Ali menambahkan kurangnya pengetahuan dan pemahaman ini berakibat kesadaran dan keinginan untuk mengeluarkan zakat berkurang, terlebih ada pemahaman bahwa mengeluarkan zakat akan mengurangi harta (Ali, 1988: 53-54).

Masalah lain dalam pendistribusian zakat adalah kurangnya kepercayaan masyarakat terhadap lembaga zakat selain karena pemahaman fiqh klasik bahwa zakat lebih afdhal ketika disalurkan langsung (secara individu) kepada mustahik, juga karena pengelolaan zakat yang tidak transparan dan akuntabel terutama yang dikelola pemerintah sehingga menjadikan masyarakat lebih senang mendistribusikan zakat secara individu. Hal ini senada 
dengan ungkapan Hamy Wahjunianto, Ketua Umum Forum Zakat (FOZ) bahwa kepercayaan publik terhadap lembaga zakat yang dibentuk masyarakat (LAZ) jauh lebih kuat dibandingkan lembaga zakat yang dibentuk pemerintah (BAZ). Ini dibuktikan dengan penghimpunan ZIS oleh LAZ lebih besar dibanding penghimpunan oleh BAZ, begitu juga jumlah donatur dan muzakki (Anonim, Jurnal Pemikiran dan Gagasan, Vol. 1, No. 4 Agustus 2008).

Tidak beda jauh, problematika pendistribusian zakat di atas juga terjadi di desa Bunut Baok Kecamatan Praya. Pendistribusian zakat masih diperuntukan pada kegiatan yang bersifat konsumtif, sekedar pemenuhan kebutuhan dasar dan tidak ada upaya untuk menyalurkan zakat pada kegiatan yang bersifat produktif untuk kemandirian dan pemberdayaan ekonomi masyarakat. Di samping itu, tidak ada lembaga atau organisasi zakat seperti Lembaga Amil Zakat tingkat desa yang menghimpun dan menyalurkan zakat, sehingga ada kecenderungan zakat diberikan pada orang yang tidak tepat dan tidak masuk dalam prioritas mustahik zakat. Dengan kata lain, ada tendensi kekeluargaan dan balas jasa dalam pemberian zakat, bukan karena benar-benar berhak menerima zakat tersebut (Wawancara, tanggal 20 Februari 2016).

\section{Pemahaman Masyarakat Desa Bunut Baok Tentang Pemanfaatan Zakat}

Zakat merupakan salah satu rukun Islam yang sifatnya wajib untuk dilaksanakan. Zakat dikeluarkan oleh seorang muslim yang memiliki harta dan mencapai ketentuan zakat yakni telah mencapai haul dan nisab. Zakat adalah salah satu bentuk ibadah yang bernilai sosial, sebagai wujud berbagi dengan sesama dan membantu orangorang yang tidak mampu dalam memenuhi kebutuhan hidupnya.

Zakat adalah sumber dana yang potensial untuk mewujudkan kesejahteraan masyarakat. Zakat sebagai kewajiban bagi umat Islam yang jika dijalankan dengan semestinya dapat dijadikan sebagai salah satu potensi ekonomi umat yang dapat dijadikan sumber dana yang dapat dimanfaatkan bagi kesejahteraan umat Islam, terutama untuk menanggulangi kemiskinan dan menghilangkan kesenjangan 
sosial. Zakat, selain berfungsi sebagai sarana mendekatkan diri kepada Allah, juga berfungsi sebagai sarana penciptaan kerukunan hidup antara golongan kaya dan miskin. Selain itu, mengeluarkan zakat dapat mencegah monopoli harta kekayaan oleh orang-orang kaya. Selain sebagai kewajiban umat Islam, zakat merupakan pranata keagamaan dalam upaya mewujudkan keadilan sosial bagi seluruh umat Islam.

Agar menjadi sumber dana yang dapat dimanfaatkan bagi kesejahteraan masyarakat, perlu adanya pemahaman yang secara utuh dan menyeluruh tentang pemanfaatan zakat, jangan sampai dipahami secara parsial. Upaya dalam memberikan kesadaran dan pemahaman tentang pemanfaatan zakat dibutuhkan keterlibatan semua pihak termasuk tokoh agama. Berdasarkan hasil observasi dan wawancara dengan beberapa mustahik zakat dan tokoh agama di Desa Bunut Baok menyimpulkan bahwa:

\section{Masyarakat belum memahami jenis-jenis qakat mal.}

Hasil penelitian ini senanda dengan hasil survey di 5 kota besar Indonesia yaitu DKI Jakarta, Bogor, Depok, Tangerang dan Bekasi (Jabodetabek) pada tahun 2010. survey tersebut menyimpulkan bahwa level pengetahuan masyarakat tentang perbedaan zakat maal dan fitrah baik. Akan tetapi pengetahuan tersebut tidak disertai dengan pemahaman cukup tentang jenis-jenis zakat maal (Sutisna, 2010).

Selain itu, Nana menuturkan, hasil survei IMZ 2010 menyimpulkan meskipun masyarakat Jabodetabek yang memiliki akses informasi lebih banyak akan tetapi masyarakat belum percaya dengan pengelolaan zakat yang sudah ada. Terbukti, sebanyak 246 responden mengaku tidak menunaikan zakat maal. Sehingga tingkat pengetahuan, akses informasi, dan level social ekonomi tidak serta merta menjamin persepsi publik tentang zakat maal turut besar pula. 
Belum ada upaya merubah bentuk qakat kebentuk lainnya, karena masyarakat dalam memahami zakat berdasarkan fiqh klasik.

Muzakki mengeluarkan zakat berupa barang yang dikenakan wajib zakat. Namun, narasumber lain memberikan keterangan yang sedikit berbeda tentang benda zakat yang dikeluarkan. Narasumber tersebut menuturkan bahwa pada setiap panen padi, baik musim tanam pertama (musim hujan) maupun musim tanam kedua zakat padi tersebut dijual dan dibagikan kepada anak-anak usia sekolah maupun yang sedang melanjutkan ke perguruan tinggi. Dijualnya zakat padi tersebut dengan alasan supaya dibagi dengan merata dan biasanya uang lebih bermanfaat untuk mereka guna membeli alatalat perlengkapan sekolah, misalnya tas, buku, pulpen dan lainlainya. Selain itu juga, zakat yang diberikan berupa padi pada ujungujungnya akan dijual oleh mereka untuk diuangkan (Wawancara, tanggal 8 April 2016).

Praktek semacam ini biasanya didasarkan pada keyakinan yang berkembang di masyarakat bahwa zakat merupakan perintah agama yang bersifat pribadi dan bukan kewajiban sosial yang harus diatur melalui mekanisme di luar ketentuan agama. Hal ini juga dinyatakan oleh Hafidhuddin bahwa salah satu penyebab belum optimalnya pengumpulan zakat dan belum dirasakan fungsinya karena pengetahuan serta pemahaman masyarakat terhadap harta yang wajib dikeluarkan zakatnya masih terbatas pada sumber-sumber konvensional yang secara jelas dinyatakan dalam al Qur'an dan Hadits dengan persyaratan tertentu (Hafidhuddin, 2002:2).

Pemanfaatan zakat bersifat tradisional atau lebih cenderung diarabkan kepada hal-hal yang bersifat konsumsif.

Esensi dari zakat sendiri adalah selain untuk memenuhi kebutuhan konsumtifnya juga memenuhi segala kebutuhan hidupnya termasuk pendidikan, tempat tinggal dan sandang. Pola pemberian zakat kepada para mustahiq tidak hanya bersifat konsumtif saja, namun dapat pula bersifat produktif. pendayagunaan zakat secara produktif yang pemahamannya lebih kepada bagaimana cara atau metode menyampaikan dana zakat 
kepada sasaran dalam pengertian yang luas, sesuai dengan tujuan syara'. Cara pemberian yang tetapt guna efektif manfaatnya dengan sistem yang serbaguna dan produktif, sesuai dengan pesan syariat dan peran serta fungsi sosial ekonomis dari zakat.

Zakat juga merupakan ibadah maaliyah ijtimaiyah yang memiliki posisi yang sangat penting, strategis, dan menentukan, baik dari sisi ajaran maupun sisi pembangunan dan kesejahteraan ummat apabila dilakukan secara optimal. Kelebihan dari zakat produktif akan berdampak positif secara nyata dalam menciptakan kesenjangan hidup masyarakat yang sejahtera yang mampu hidup lebih baik lagi dan bahkan akan lebih mandiri, sehingga ia tidak butuh lagi menerima zakat. Karena telah mampu bangun dari kemiskinan menuju kaya dan sejahtera.

Menurut S.A. Siddiqi (1984:v-vi) zakat pada zaman nabi digunakan untuk menyelesaikan ketidakmerataan ekonomi, kemudian zakat juga menjadi panduan bagi para khalifah setelah nabi dalam menyelesaikan ketimpangan ekonomi antara si miskin dan si kaya. Dan zakat juga sebaiknya dijalankan umat Muslim untuk menyelesaikan masalah kemiskinan dan ketimpangan ekonomi yang terjadi sekarang ini. Pada beberapa negara Arab, zakat merupakan sumber pendapatan utama disamping pajak-pajak lain seperti pajak tanah, hasil bumi dan lain-lain.

Zakat yang dimanfaatkan pada hal yang bersifat produktif ini sangat urgen dalam membangun masyarakat produktif dan inovatif dalam membangun bersama perekonomian bangsa sejahtera. Salah satu bentuk zakat produktif itu ialah yang diinvestasikan. Investasi dana zakat dapat disalurkan pada usaha yang dihalalkan syariat dan peraturan yang berlaku, usaha itu di yakini memberi keuntungan berdasarkan studi kelaikan, pembinaan dan pengawasan oleh pihak berkompeten termasuk lembaga yang mengelola dana investasi itu. Juga tidak terdapat fakir miskin yang kelaparan dan memerlukan biaya serta tak bisa ditunda saat zakat diinvestasikan.

Skala prioritas dapat menjadi perhatian amil zakat dan muzakki jika dana yang terkumpul hanya sedikit maka prioritas utama adalah mustahiq yang sangat membutuhkan terutama dalam bentuk zakat 
konsumsi, sedangkan jika dana yang terkumpul lebih dari cukup maka dapat digunakan untuk seluruh asnaf atau untuk investasi produktif yang melibatkan kelompok fakir miskin serta hasilnya dapat dimanfaatkan, selain itu juga dapat dipergunakan untuk program pengentasan kemiskinan dengan menyalurkan zakat untuk usaha produktif baik dalam bentuk modal usaha, alat-alat usaha, pelatihan keterampilan, bimbingan usaha dan lain-lain.

Orientasi pengelolaan zakat produktif dapat dipahami bersamasama secara komprehensif oleh semua masyarakat (muzaki, amil dan mustahiq). Memahami tujuan dari pengelolaan zakat produktif yaitu untuk kesejahteraan masyarakat, seperti yang disebutkan dalam UU No. 23 Tahun 2011 bahwa pengelolaan zakat bertujuan untuk meningkatkan efektifitas dan efesiensi pelayanan dalam pengelolaan zakat dan mewujudkan kesejahteraan masyarakat dan penanggulangan kemiskinan.

Merubah paradigma distribusi zakat dari konsumtif oriented kepada produktif oriented adalah tugas bersama semua lapisan masyarakat, agar kemiskinan lebih efektif bisa diberantas. Bila kebiasaan konsumtif di atas berlanjut, niscaya zakat dan sedekah tak banyak pengaruhnya mengentaskan kemiskinan. Sedekah untuk konsumtif memang mulia. Hanya, jauh lebih mulia jika sedekah pun dijadikan modal untuk mengubah dhuafa. Kini saatnya kita mengubah paradigma berzakat. Memaksa bekerja lebih mulia ketimbang santunan. Untuk melakukan ini, maka berzakat sebaiknya diserahkan kepada lembaga amil zakat yang amanah dan terpercaya.

Beberapa permasalahan tentang pemanfaatan zakat di Desa Bunut Baok diperlukan langkah-langkah strategis. Salah satu tokoh agama di Desa Bunut Baok menjelaskan bahwa upaya sosialisasi zakat secara intensif tentang pemanfaatan zakat sangat dibutuhkan kepada para petani, baik melalui pengajian umum atau majlis taklim dan perkumpulan arisan yang disertai ceramah kecil serta kegiatan lainnya yang mampu disampaikan kepada masyarakat umum/publik (Wawancara, tanggal 7 Juni 2016). 
Langkah sosialisasi ini selayaknya dilakukan secara berkelanjutan, yang tak hanya terpaku pada momen tertentu saja. Tak kalah penting, upaya tersebut mesti dilakukan melalui masjidmasjid yang merupakan ujung tombak aktivitas umat Islam. Sudah saatnya lembaga amil zakat dekat dengan masjid karena di masjidlah edukasi paling kuat.

\section{Mekanisme Pendistribusian Zakat di Desa Bunut Baok}

Zakat merupakan salah satu kewajiban muslim yang harus dilakukan terutama bagi yang memiliki harta dan telah mencapai nisab dan haul sesuai dengan ketentuan syariah Islam. Zakat diberikan kepada mustahik (penerima zakat) untuk membantunya dalam menyelesaikan masalah ekonomi yang dihadapi. Zakat diharapkan dapat meningkatkan ekonomi mustahik yang pada ujungnya dapat menjadi orang yang mengeluarkan zakat (muzakki).

Zakat adalah kewajiban setiap muslim yang mampu menunaikannya, dan diperuntukkan bagi mereka yang berhak menerimanya sesuai dengan tuntunan Alquran dan hadis Nabi SAW. Akan tetapi, dalam kenyataannya kaum muslimin masih banyak yang belum menunaikan tuntunan agama ini, padahal zakat merupakan sumber dana potensial yang dapat dimanfaatkan untuk kesejahteraan umat.

Zakat mempunyai aspek Habl min Allâh, yaitu hubungan manusia dengan Allah SWT. di mana zakat sebagai sarana beribadah untuk mendekatkan diri kepada-Nya, dan aspek Habl min al-Nâs, yaitu hubungan manusia dengan manusia, di mana zakat dapat berperan untuk mempersempit jurang perbedaan dan ketimpangan serta kesenjangan sosial sehingga zakat dapat membersihkan manusia dari sifat loba, rakus, dan bakhil sehingga menjadi pribadi-pribadi yang bersih, jujur, penuh toleransi, dan kesetiakawanan sosial yang tinggi.

Kepemilikan harta benda oleh aghniyấ (orang-orang kaya) pada hakikatnya adalah titipan (amanah) dari Allah Swt., sedangkan hak milik mutlak hanya ada pada Allah Swt. Oleh karena itu, harta kekayaan menurut Islam memiliki fungsi sosial, yaitu tidak saja 
untuk kepentingan pribadi, tetapi juga untuk kepentingan masyarakat muslim dan agama.

Berdasarkan hasil observasi yang dilakukan selama penelitian dan wawancara dengan beberapa narasumber ditemukan bahwa mekanisme dalam pendistribusian zakat di desa Bunut Baok adalah bersifat tradisional dan individual. Artinya masing-masing muzakki menyerahkan zakat secara langsung kepada siapa yang dianggap berhak menerima zakat. Pendistribusian zakat dengan cara tersebut tidak tepat sasaran karena adanya tendensi kekeluargaan dan balas budi atas apa yang diberikan oleh mustahik kepada muzakki.

Irfan Abubakar, Direktur Center for the Study of Religion and Culture (CSRC) Universitas Islam Negeri (UIN) Syarif Hidayatullah Jakarta menegaskan bahwa pola menyalurkan zakat masyarakat masih tradisional dan berpatok pada kebiasaan. Berdasarkan penelitian CSRC, hanya 5,3 persen masyarakat yang membayar zakat maal mereka ke lembaga-lembaga amil zakat. Sebesar 60 persen lebih memilih menyalurkan zakat mereka secara langsung baik ke masjid ataupun individu mustahik. Bahkan, sebanyak 85 persen masyarakat beralasan merasa lebih puas menyerahkan langsung ke mustahik daripada menyalurkannya ke lembaga (www.republika.co.id).

Selain itu, di Desa Bunut Baok juga belum ada lembaga khusus yang mengumpulkan dan mendistribusikan zakat seperti Bazdes (Badan Amil Zakat Desa). Padahal lembaga tersebut sudah ada payung hukum yakni Undang-Undang nomor 38 tahun 1999. Dalam undang-undang tersebut memuat aturan tentang pengelolaan yang terorganisir dengan baik, transparan dan professional dilakukan oleh amil resmi yang ditunjuk oleh pemerintah yaitu Badan Amil Zakat (BAZ) dan lembaga Amil Zakat (LAZ).

Masdar F. Mas'udi menegaskan bahwa zakat merupakan satusatunya amalan yang membahas tentang keadilan sosial atau pemerataaan akses sumber daya materi. Konsep dasar zakat sebagai mekanisme redistribusi kekayaan adalah pengalihan sebagian aset materi yang dimiliki kalangan kaya yang memiliki lebih dari yang diperlukan) untuk kemudian didistribusikan pada mereka yang tak 
punya. Seyogyanya pengalihan itu dilaksanakan kalangan berada atas kesadaran mereka sendiri. Tetapi karena manusia mengindap nafsu "cinta harta" (bub-u 'l-durya). Maka kehadiran lembaga yang melakukan pengalihan tersebut menjadi tidak terelakan (Mas'udi, 1995:425).

Dalam konteks ini, Pemerintah desa berkewajiban memberikan perlindungan, pembinaan dalam pelayanan kepada muzaki, mustabik dan pengelola zakat. Pelaksanaan dan pengawasan terhadap pengumpulan dan pendistribusian serta pendayagunaan zakat. Pengelolaan zakat dilakukan untuk meningkatkan pelayanan bagi masyarakat dalam menunaikan zakat sesuai dengan tujuan agama, meningkatkan fungsi dan peranan pranata keagamaan dalam upaya mewujudkan kesejahteraan masyarakat dan keadilan sosial yang dilaksanakan sebagai upaya penyempurnaan sistem pengelolaan zakat yang perlu terus ditingkatkan agar pelaksanaan zakat lebih berhasil guna dan berdaya guna serta dapat dipertanggungjawabkan. Zakat, dilihat dari prinsip keuangan negara modern, dapat dibedakan dengan sumber-sumber keuangan negara lainnya, walaupun sifat religio-ekonomis-nya sulit dibandingkan dengan sumber keuangan negara modern yang terdiri atas pajak, upah, harga, taksiran khusus, tarif, dan sebagainya. Di era modern ini, sebaiknya zakat dimanfaatkan untuk kepentingan sosial dan produktivitas ekonomi.

Namun Masyarakat tidak tertarik untuk menyerahkan zakatnya kepada lembaga-lembaga yang dibentuk Pemerintah karena selain kurangnya kepercayaan masyarakat kepada Pemerintah dalam hal pengelolaan zakat, juga karena kuatnya anggapan masyarakat bahwa zakat tersebut adalah masalah ibadah sehingga seharusnya ditunaikan secara pribadi tanpa harus ada campur tangan Pemerintah.

Dalam persepsi masyarakat, keberadaan amil zakat sebagai pengelolah zakat merupakan perpanjangan tangan Pemerintah dalam pengelolaan zakat karena BAZ diprakarsai pembentukanya oleh Pemerintah dan sebagian pengurusnya adalah dari unsur Pemerintah. Sementara masyarakat awam memandang zakat itu 
sebagai institusi keagamaan semata dengan mengabaikan zakat sebagai institusi sosial. Zakat lebih diyakini sebagai salah satu ibadah kepada Allah dan sehingga pelaksanaanya pun harus bersifat pribadi, tidak perlu ada campur tangan Pemerintah dalam pengelolaanya. Hal tersebut didukung oleh jawaban responden yang lebih banyak mengaggap zakat sebagai intitusi keagamaan, meskipun ada juga yang berkedudukan sebagai pengumpul zakat. Selain itu, ada pandangan masyarakat bahwa BAZ belum profesional dalam mengelolah zakat.

Badan Amil Zakat (BAZ) telah berupaya secara maksimal mengelolah zakat secara profesional, meskipun belum secara optimal mengelolah zakat sebagai potensi ekonomi umat Islam. Hal ini disebabkan oleh (1) faktor kurangnya sumber daya manusia pengelolah BAZ; (2) faktor kesadaran umat Islam yang belum memahami esensi zakat; dan (3) faktor kelembagaan serta pengelolaan potensi zakat di lapangan. Hal tersebut mengindikasikan perlunya badan amil zakat tingkat desa yang perlu dibentuk untuk mengumpulkan dan mendistribusikan zakat sesuai dengan syariah Islam.

\section{Problematika Pendistribusian Zakat di Desa Bunut Baok}

Zakat merupakan kewajiban yang dikeluarkan oleh muzakki atau orang yang berkewajiban mengeluarkan zakat. Hal ini dikarenakan dalam harta terdapat hak orang lain yang harus dikembalikan kepada yang berhak menerimanya sebagai wujud pensucian harta. Zakat merupakan Ibadah yang mengandung dua dimensi yaitu dimensi hablumminalloh atau hubungan manusia dengan Allah SWT dan dimensi hablumminannas atau hubungan manusia dengan manusia.

Zakat juga berperan penting dalam mewujudkan terciptanya keadilan dalam bidang ekonomi di mana seluruh anggota warga negara mempunyai sumber pendapatan dan income untuk memenuhi kebutuhan sehari-hari dalam rangka menjalankan roda kehidupan dimuka bumi ini. Oleh karena diperlukan lapangan pekerjaan yang cukup sebagai sumber atau ladang pendapatan yang halal. Dengan 
zakat maka akan terkumpul dana baru (fresh capital) yang bebas dari tekanan-tekanan apapun karena memang bersifat sukarela dan merupakan hak para kaum miskin. Berdasarkan hasil observasi dan wawancara dengan beberapa narasumber ditemukan problematika dalam pendistribusian zakat di desa Bunut Baok, antara lain:

\section{Zakat disalurkan hanya untuk memenubi kebutuban pokok sehari-hari atau konsumtif}

Desa Bunut Baok termasuk daerah persawahan yang memiliki lahan pertanian cukup luas. Warga yang berprofesi sebagai petani di Desa Bunut Baok menanam padi dua kali setahun sehingga kontribusi zakat hasil pertanian cukup besar, seperti padi. Zakat padi tersebut diberikan langsung oleh muzakki kepada mustahik. Zakat yang diberikan tersebut digunakan oleh mustahik untuk memenuhi kebutuhan hidupnya sehari-hari.

Zakat yang diberikan oleh muzakki kepada mustahik zakat meskipun mampu membantu fakir miskin memenuhi kebutuhan hidup sehari-hari yang mendesak, cara pemanfaatan zakat seperti ini cenderung mengabadikan si penerima zakat dalam situasi kemiskinannya.

A. Qodri Azizy dalam bukunya menyimpulkan bahwa zakat hendaknya tidak sekedar konsumtif, maka idealnya zakat dijadikan sumber dana umat. Penggunaan zakat untuk konsumtif hanyalah untuk hal-hal yang bersifat darurat. Artinya, ketika ada mustahiq yang tidak mungkin untuk dibimbing untuk mempunyai usaha mandiri atau memang untuk kepentingan mendesak, maka penggunaan konsumtif dapat dilakukan (Azizy, 2004:148-149).

Zakat yang diberikan dalam bentuk barang-barang yang produktif seperti kambing, sapi, alat cukur, dan lain-lain sebagainya. Pemberian dalam bentuk ini akan menciptakan suatu usaha yang membuka lapangan kerja fakir miskin. Selain itu, zakat juga dapat diberikan berupa modal usaha. Dengan berkembangnya usaha kecil menengah dengan modal berasal dari zakat akan menyerap tenaga kerja. Hal ini berarti angka pengangguran bisa dikurangi, berkurangnya angka pengangguran akan berdampak pada 
meningkatnya daya beli masyarakat terhadap suatu produk barang ataupun jasa, meningkatnya daya beli masyarakat akan diikuti oleh pertumbuhan produksi, pertumbuhan sektor produksi inilah yang akan menjadi salah satu indikator adanya pertumbuhan ekonomi.

Dalam hal ini Nabi Muhammad SAW telah mencontohkan dengan keteladanan yang beliau lakukan ketika memberikan kepada seorang fakir sebanyak dua dirham sambil memberikan anjuran agar mempergunakan uang tersebut, satu dirham untuk dimakan dan satu dirham lagi supaya dibelikan kapak sebagai alat kerja. Untuk penganti pemerintah saat ini dapat diperankan oleh badan amil zakat atau lembaga amil zakat yang kuat, amanah, dan profesional. BAZ atau LAZ bila memberikan zakat yang bersifat produktif harus pula melakukan pembinaan atau pendampingan kepada mustahiq zakat agar kegiatan usahanya dapat berjalan dengan baik, dan agar para mustahik semakin meningkat kualitas keimanan dan keIslamnnya. Dengan model yang produktif, tepat sasaran serta berkelanjutan, zakat diharapkan dapat meningkatkan kesejahteran dan membebaskan diri dari belenggu kesengsaraan ekonomi, serta mengangkat derajat setatus kaum dhuafa (mustahiq) menjadi muzaki dikemudian hari.

Tidak ada lembaga yang mengelola dan mendistribusikan zakat kepada masyarakat.

Desa Bunut adalah salah desa yang ada di kecamatan praya kabupaten lombok tengah. Desa bunut termasuk daerah pertanian terluas kedua setelah jago. Artinya potensi zakat dari hasil pertanian sangat besar dan potensial untuk membantu masyarakt yang tidak mampu untuk menyelesaikan problem ekonominya.

Namun, berdasrkan hasil observasi di lapangan ditemukan bahwa besarnya potensi zakat tersebut tidak dibarengi dengan pengelolaan yang bagus karena tidak ada lembaga khusus yang menangani manajemen pengelolaan zakat tersebut seperti Badan Amil Zakat Desa (BAZDES). Masyarakat langsung secara individual menyerahkan zakat kepada mustahik sehingga kontribusi 
zakat untuk mengentaskan kemiskinan tidak ada berpengaruh besar.

Urgensinya pembentukan suatu lembaga untuk mengelola zakat sehingga Maulana Muhammad Ali berpendapat hendaknya diingat bahwa zakat bukanlah hanya sekedar dana yang diwajibkan. Zakat adalah lembaga negara, atau jika tak ada negara Islam, zakat adalah lembaga nasional. Orang tak dibenarkan menghitung dan membelanjakan zakatnya sesukanya sendiri. Zakat harus dipungut dan dikumpulkan oleh pemerintah atau lembaga nasional, dan harus dibagikan oleh pemerintah atau masyrakat. Al-Qur'an telah menggarisbawahi siapa-siapa yang harus diberi bagian zakat, yang dalam ayat ini disebutkan sebuah fasal bahwa salah satu yang harus diberi zakat adalah pegawai yang ditetapkan untuk memungut dan membagi zakat Ini menunjukkan seterang-terangnya bahwa lembaga zakat harus dibentuk menjadi satu departemen pemerintahan, atau paling tidak baitul-mal, yang harus digunakan untuk meningkatkan kesejahteraan masyarakat.

Kompleksitas masalah zakat dan potensinya yang sangat besar dalam membangun ekonomi sudah saatnya harus dikelola secara profesional, hal ini terbukti dilapangan bahwa sebagian besar pengelolaan zakat belum mengarah pada pengelolaan secara profesional terutama pada lembaga Badan Amil Zakat dan lemahnya professionalitas pengelolaan pada Badan Amil Zakat menjadikan badan amil zakat masih belum memberikan kontribusi penuh terhadap peningkatan kesejahteraan umat.

Keberadaan lembaga zakat menempati posisi sentral dalam memberikan kontribusi terahadap kesejahteraan mustahik atau penerima zakat dalam sebuah wilayah atau daerah tertentu. Begitu juga dengan keberadaan BAZDES.

BAZDES merupakan perpanjangan tangan dari BAZDA sekarang BAZNAS Lombok Tengah dalam hal penghimpunan dan penyaluran zakat. Potensi zakat dari hasil pertanian khususnya padi. Masyarakat Desa Bunut Baok didomanasi oleh petani disamping mata pencarian yang lain. Bedasarkan pengamatan sementara masyarakat Desa Bunut Baok tidak sedikit dari mereaka yang 
mencari nafkah keluar negeri (TKI) ini membuktikan bahwa kurangnya lapangan kerja yang mengharuskan mereka mencari nafkah keluar negeri untuk untuk mencukupi kehidupan keluarnganya. Keadaan perekonomian masyarakat Desa Bunut Baok terutama masyarakat yang tinggal dipelosok-pelosok dusun yang terpencil, ada dari mereka yang tidak sekolah khususnya bagi anak-anak, dan dari mereka juga terdapat orang-orang tua jompo yang seharusnya mendapatkan perhatian penuh dari pemerintah. Dengan berdirinya BAZDES di Desa Bunut Baok sekiranya akan membantu kekurangan mereka dalam memenuhi kebutuhan hidupnya.

\section{Muzakeki menyalurkan zakat secara individual}

Praktek semacam ini biasanya didasarkan pada keyakinan yang berkembang di masyarakat bahwa zakat merupakan perintah agama yang bersifat pribadi dan bukan kewajiban sosial yang harus diatur melalui mekanisme di luar ketentuan agama. Hal lain juga sebagai salah satu penyebab belum optimalnya pengumpulan zakat dan belum dirasakan fungsinya karena pengetahuan serta pemahaman masyarakat terhadap harta yang wajib dikeluarkan zakatnya masih terbatas pada sumber-sumber konvensional yang secara jelas dinyatakan dalam al Qur'an dan Hadits dengan persyaratan tertentu.

Kurangnya kepercayaan masyarakat terhadap lembaga zakat selain karena pemahaman fiqh klasik bahwa zakat lebih afdhal ketika disalurkan langsung (secara individu) kepada mustahik, juga karena pengelolaan zakat yang tidak transparan dan akuntabel terutama yang dikelola pemerintah sehingga menjadikan masyarakat lebih senang mendistribusikan zakat secara individu. Kepercayaan publik terhadap lembaga zakat yang dibentuk masyarakat (LAZ) jauh lebih kuat dibandingkan lembaga zakat yang dibentuk pemerintah (BAZ). Ini dibuktikan dengan penghimpunan ZIS oleh LAZ lebih besar dibanding penghimpunan oleh BAZ, begitu juga jumlah donatur dan muzakki. 
Belum ada upaya penyaluran zakat dalam bentuk lain, misalnya beasiswa atau modal usaha

zakat yang sudah terkumpul disalurkan dalam bentuk beasiswa untuk pelajar atau pendanaan untuk mengadakan pelatihan yang berbasis keterampilan hidup (life skill). Keterampilan hidup merupakan upaya untuk meningkatkan keterampilan, pengetahuan, sikap dan kemampuan yang memungkinkan warga belajar dapat hidup mandiri. Hal tersebut penting diberdayakan pada umat disaat persaingan yang semakin ketat.

Dalam Undang-Undang No 38 Tahun 1999 Tentang Pengelolahan Zakat, Bab V (Pendayagunaan Zakat) Pasal 16 dijelaskan bahwa dalam kaitan memaksimalkan fungsi zakat, maka pola pemberian zakat tidak terbatas pada yang bersifat konsumtif, tetapi harus lebih yang bersifat produktif. Yang artinya bahwa zakat sebaiknya diwujudkan dalam bentuk permodalan untuk pembangunan proyek sosial atau menambah modal usaha pengusaha kecil.

Belum ada upaya mengumpulkan dan menyalurkan zakat profesi.

Zakat profesi dikenal dengan istilah zakah rawatib al-muwazhaffin (zakat gaji pegawai) atau zakah kash al-'amal wa al-mihan al-hurrah (zakat hasil pekerjaan dan profesi swasta). Zakat profesi didefinisikan sebagai zakat yang dikenakan pada tiap pekerjaan atau keahlian profesional tertentu, baik yang dilakukan sendiri maupun bersama orang atau lembaga lain, yang mendatangkan penghasilan (uang) yang memenuhi nishab.

Zakat profesi merupakan perkembangan kontemporer, yaitu disebabkan adanya profesi-profesi modern yang sangat mudah menghasilkan uang. Misalnya profesi dokter, konsultan, advokat, dosen, arsitek, dan sebagainya. Kenyataan membuktikan bahwa pada akhir-akhir ini banyak orang yang karena profesinya, dalam waktu yang relatif singkat, dapat menghasilkan uang yang begitu banyak. Kalau persoalan ini dikaitkan dengan pelaksanaan zakat yang berjalan di masyarakat maka terlihat adanya kesenjangan atau ketidakadilan antara petani yang memiliki penghasilan kecil dan 
mencurahkan tenaga yang banyak dengan para profesional misalnya dokter, akuntan, konsultan, notaris, dan insinyur yang hanya dalam waktu relatif pendek memiliki hasil yang cukup besar tanpa harus mencurahkan tenaga yang banyak.

Adapun pekerjaan atau keahlian profesional tersebut bisa dalam bentuk usaha fisik, seperti pegawai atau buruh, usaha pikiran dan ketrampilan seperti konsultan, insinyur, notaris dan dokter, usaha kedudukan seperti komisi dan tunjangan jabatan, dan usaha lain seperti investasi. Hasil usaha profesi juga bisa bervariasi, misalnya hasil yang teratur dan pasti setiap bulan, minggu atau hari seperti upah pekerja dan pegawai atau hasil yang tidak tetap dan tidak dapat diperkirakan secara pasti, seperti kontraktor dan royalti pengarang.

Landasan hukun diwajibkan mengeluarkan zakat profesi ada dalam Qs. Al-Baqarah (2): 267 sangat jelas menyebutkan bahwa "Anfiqu min toyyiba ti ma kasabtum" (nafkahkanlah/ zakatkanlah sebagian dari hasi usaha yang baik). Makna kasabtum jelas mengandung makna apa yang kita usahakan, baik di level birokrasi/lembaga atau yang dihasilkan dari usaha pribadi. Landasan normatif yang terkandung di dalam al-Quran tersebut mengandung spirit nilai kedermawanan dalam Islam, yaitu kekuatan kuratif bagi para muzakki agar terhindar dari nilai-nilai tamak, serakah, dan penyakit hati lainnya yang berbau material.

Kewajiban zakat disejajarkan dengan kewajiban solat dalam nash al-Qur'an. Ini menunjukkan bahwa kewajiban zakat itu merupakan kewajiban yang sifatnya fardu 'ain yang harus segera dikeluarkan sejajar dengan kewajiban solat itu sendiri. Selanjutnya dalam pelaksanaannya, mengeluarkan zakat profesi bagi PNS tidak harus menunggu haul karena diqiyaskan kepada zakat pertanian.

Desa Bunut Baok termasuk daerah pertanian yang memiliki lahan persawahan terluas kedua di Kecamatan Praya. Sumbangsih pertanian terhadap zakat sangat besar. Namun, potensi zakat yang lain belum oftimal dikumpulkan seperti zakat profesi. Padahal penduduk Desa Bunut Baok banyak yang berprofesi sebagai pegawai negeri sipil karyawan swasta. 
Ada beberapa problem zakat profesi di desa Bunut Baok, antara lain: pertama, kurangnya pemahaman dan kesadaran masyarakat tentang kewajiban mengeluarkan zakat profesi jika sudah memenuhi nisab dan haul sesuai dengan ketentuan syariat Islam. Kedua, tokoh agama kurang maksimal dalam mensosialisasikan atas kewajiban zakat tersebut, pengajian hanya berisi masalah ibadah individual yang syarat dengan mengesampingkan ibadah sosial, padahal zakat termasuk rukun Islam.

Ketiga, Problem yang lain adalah tidak ada petugas khusus yang ditunjuk untuk memungut zakat profesi. Artinya muzakki harus ada inisiatif sendiri untuk mengumpulkan dan menyalurkan zakat tersebut kepada mustahik zakat sesuai dengan ketetapan ajaran Islam yang terdapat pada Al-qur'an dan Al-hadis yaitu kepada delapan golongan.

Untuk menyadarkan masyarakat tentang zakat profesi maka diperlukan kegiatan sosialisasi dengan berbagai macam strategi. Hasil penelitian Muslihun menjelaskan bahwa kiat-kiat sosialisasi yang efektif dalam menarik simpati calon muzakki profesi, yakni (a) dengan mendatangi wajib pajak lalu dilakukan ceramah dan penjelasan tentang seluk beluk zakat profesi, (b) dengan menyebarkan pamplet dan brosur serta tulisan-tulisan yang berkenaan dengan zakat profesi, (c) dengan melakukan diskusi dan tanya jawab lewat media TV dan radio, (d) dengan mempublikasikan semua kegiatan Baznas khususnya tentang zakat profesi di media cetak (Muslihun, Jurnal Penelitian Keislaman, Vol. 10, No. 1, Januari 2014).

\section{Catatan Akhir}

Berdasarkan hasil dan pembahasan di atas, dapat disimpulkan: Pertama, berkaitan dengan pemahaman masyarakat desa Bunut Baok tentang pemanfaatan zakat anatara lain: (a) masyarakat belum memahami jenis-jenis zakat mal; (b) belum ada upaya merubah bentuk zakat kebentuk lainnya, karena masyarakat dalam memahami zakat berdasarkan fiqh klasik; (c) pemanfaatan zakat bersifat tradisional atau lebih cenderung diarahkan kepada hal-hal 
yang bersifat konsumsif. Kedua, mekanisme pendistribusian zakat di desa Bunut Baok bersifat tradisional dan individual. Ketiga, problematika pendistribusian zakat di desa Bunut Baok antara lain: (1) zakat disalurkan hanya untuk memenuhi kebutuhan pokok sehari-hari atau konsumtif; (2) tidak ada lembaga yang mengelola dan mendistribusikan zakat kepada masyarakat; (3) muzakki menyalurkan zakat secara individual; (4) belum ada upaya penyaluran zakat dalam bentuk lain, misalnya beasiswa atau modal usaha dan; (5) belum ada upaya mengumpulkan dan menyalurkan zakat profesi.

\section{Daftar Referensi}

Mubariq, Ahmad. Zakat untuk Pengentasan Kemiskinan Beberapa Isu Kebijakan, dalam Eko Suprayitno, Ekonomi Islam Pendekatan Ekonomi Makro Islam dan Konvensional. Yogyakarta: Graha Ilmu, 2005.

Anonim. Mengapresiasi Bangkitnya Civil Society Dalam Pengelolaan Zakat di Indonesia, dalam Zakat \& Empowering, Jurnal Pemikiran dan Gagasan, Vol. 1, No. 4 Agustus (2008).

Hafidhuddin, Didin, dkk. The Power of Zakat, ed. Sudirman dan Risma Nur Arifah. Malang: UIN Malang Press, 2008.

Hafidhuddin, Didin. Zakat Dalam Perekonomian Modern. Jakarta: Gema Insani, 2002.

Mas'udi, Masdar F. "Zakat: Konsep Harta yang Bersih" dalam Kontekstualisasi doktrin islam dalam sejarah, ed. Budhy MunawarRachman. Jakarta: Paramadina, 1995.

Ali, Mohammad Daud. Sistem Ekonomi Islam Zakat dan Wakaf. Jakarta: UI Press, 1988.

Muslihun. "Manajemen Sosialisasi Zakat Profesi dalam Menarik Simpati Wajib Zakat pada Baznas Kota Mataram dan Baznas NTB”, dalam Jurnal Penelitian Keislaman, Vol. 10, No. 1, Januari (2014).

Sutisna, Nana. "Menimbang Hasil Survei Persepsi Publik Tentang Zakal Maal dan Pengelolaannya", dalam www.republika.co.id. Diakses pada hari senin tanggal 20 Juni 2016. 
el-HiKMAH, Vol. 10, No. 2, Desember 2016

Azizy, A. Qodri. Membangun Fondasi Ekonomi Umat Meneropong Prospek Berkembangnya Ekonomi Islam), cet. 1. Yogyakarta: Pustaka Pelajar, 2004.

Tambunan, Tulus T.H. Perekonomian Indonesia: Beberapa Permasalahan Penting. Bogor: Ghalia Indonesia, 2014. 